\title{
Assessment of Outdoor Thermal Comfort and Wind Characteristics at Three Different Locations in Peninsular Malaysia
}

\author{
Mohd Hafizal Hanipah ${ }^{1, a}$, Abd Halid Abdullah ${ }^{1}$, Nor Azwadi Che Sidik ${ }^{2}$, Riduan Yunus ${ }^{1}$, Mohd Nor \\ Azam Yasin ${ }^{1}$ and Muhammad Noor Afiq Witri Muhammad Yazid ${ }^{2}$ \\ ${ }^{1}$ Faculty of Civil and Environmental Engineering, Universiti Tun Hussein Onn Malaysia, 86400 Batu Pahat, Johor \\ Malaysia \\ ${ }^{2}$ Faculty of Mechanical Engineering, Universiti Teknologi Malaysia, 81310 Skudai, Johor, Malaysia
}

\begin{abstract}
Urbanization and rapid growth in construction have led to the problems of global warming and urban heat island throughout the world. In order to reduce these problems particularly in hot and humid climatic region, a research on current level of outdoor thermal comfort and wind characteristics based on the local weather conditions around Malaysia should be conducted. This paper reports on the analysis of outdoor thermal comfort level at hottest temperatures and wind characteristics at three locations in Peninsular Malaysia by using hourly climatic data recorded by Malaysian Meteorological Department (MetMalaysia). The level of outdoor thermal comfort was assessed based on the Universal Thermal Climate Index (UTCI). The results showed extreme heat stress conditions have occurred at Alor Setar, Kuantan, and Subang with UTCI values of $51.2^{\circ} \mathrm{C}, 49.7^{\circ} \mathrm{C}$, and $49.0^{\circ} \mathrm{C}$ respectively taking into account only temperature data from the year 2012 to 2014. However, for 20 years data from 1994 to 2014 , the calculated UTCI also showed extreme heat stress conditions with their respective values of $49.6^{\circ} \mathrm{C}, 43.8^{\circ} \mathrm{C}$, and $49.7^{\circ} \mathrm{C}$ for Alor Setar, Kuantan, and Subang respectively. Meanwhile, the hourly mean wind speed for three years data at Alor Setar, Kuantan, and Subang, were $1.70 \mathrm{~m} / \mathrm{s}$, $1.69 \mathrm{~m} / \mathrm{s}$, and $1.63 \mathrm{~m} / \mathrm{s}$ respectively. The highest mean wind speed of $11.6 \mathrm{~m} / \mathrm{s}$ was observed at Subang, while no wind movement (i.e. $0 \mathrm{~m} / \mathrm{s}$ ) was considered to be the lowest hourly wind speed for all three locations. The observed prevailing wind direction for all the three locations was from the north $\left(0^{\circ}\right)$. It can be concluded that Peninsular Malaysia is generally facing extreme heat stress problem due to unfavourable climatic conditions.
\end{abstract}

\section{Introduction}

Global warming and urban heat island have become major concerns in developed and developing countries throughout the world [1-3]. Inevitably, Malaysia has also been facing this heat stress and thermal comfort problems [4-6]. The yearly mean temperature for Central Peninsular Malaysia for the period of $1969-2014$ shows an increment of $0.35^{\circ} \mathrm{C}$ per decade [7]. The warmer urban climate may have some negative impacts towards people outdoor thermal comfort in Malaysia. Major problem such as urban heat island can directly affect the outdoor human thermal comfort level. Currently in

\footnotetext{
${ }^{a}$ Corresponding author : hafizal@uthm.edu.my
} 


\section{MATEC Web of Conferences}

Malaysia, there is very limited research being conducted on these issues with regard to building construction and urban development. It is even more critical as the building arrangement parameters such as packing density $\left(\lambda_{\mathrm{p}}\right)$, frontal area density $\left(\lambda_{\mathrm{f}}\right)$, height-to-width ratio $\left(\lambda_{\mathrm{s}}\right)$ etc $[2,8-10]$ have not been considered during earlier stage of urban design. Therefore, the primary aim of this research study is to determine current extreme outdoor thermal comfort index and wind characteristics. For future studies, factors affecting outdoor thermal comfort in urban areas, and dominant building arrangement parameters in hot humid climate will be examined.

\section{Study Area}

In general, Malaysia is a South East Asian country which is located in the equatorial zone. The geographic coordinate is $2^{\circ} 30^{\prime}$ in the north latitude and $112^{\circ} 30^{\prime}$ in the east longitude. Throughout the year, Malaysia experiences a wet and humid condition with daily temperature ranging from about $24^{\circ} \mathrm{C}$ to $38^{\circ} \mathrm{C}$ [7]. Wind speed and wind direction across the Peninsular Malaysia are influenced by the monsoon seasons, namely southwest monsoon, northeast monsoon and two short inter-monsoons.

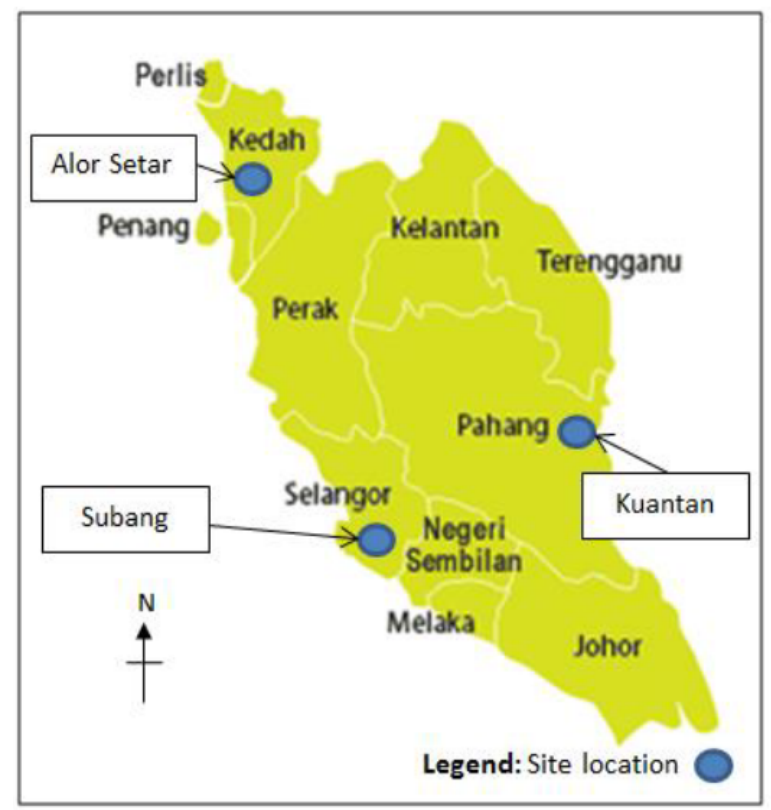

Figure 1. Map of Peninsular Malaysia showing the case study stations.

The wind speed range is below $8 \mathrm{~m} / \mathrm{s}$ during southwest monsoon season, and $5 \mathrm{~m} / \mathrm{s}$ to $10 \mathrm{~m} / \mathrm{s}$ for northeast monsoon season. While during inter-monsoons, the wind is generally light and variable. Malaysia has high humidity where the monthly mean relative humidity is ranging from $70 \%$ to $90 \%$ throughout the year varying from different places and times. In addition, Malaysia receives about 6 hours of sunshine per day on average [7]. For this study, three different locations or cities around Peninsular Malaysia were chosen; which include Alor Setar (i.e. Northern region), Kuantan (i.e. East Coast region facing the South China Sea), and Subang (i.e. Central region) as shown in Figure 1 and stated in Table 1. The weather data representing the hot and humid tropical climate of Malaysia from three principal weather stations namely Alor Star, Kuantan, and Subang were utilized to investigate outdoor thermal comfort conditions and wind characteristics of the three respective locations mentioned earlier. 
Table 1. Location of wind speed stations used in the study.

\begin{tabular}{llll}
\hline Station & Latitude & Longitude & $\begin{array}{l}\text { Height above } \\
\text { sea level (m) }\end{array}$ \\
\hline Alor Setar & $6^{\circ} 12^{\prime} \mathrm{N}$ & $100^{\circ} 24^{\prime} \mathrm{E}$ & 3.90 \\
Kuantan & $3^{\circ} 46^{\prime} \mathrm{N}$ & $103^{\circ} 13^{\prime} \mathrm{E}$ & 15.20 \\
Subang & $3^{\circ} 08^{\prime} \mathrm{N}$ & $101^{\circ} 33^{\prime} \mathrm{E}$ & 16.60 \\
\hline
\end{tabular}

\section{Methods}

The hourly data for wind speed and direction within the three years period of 2012-2014 were obtained from the MetMalaysia. The hottest temperature of the day for the past 20 years from 19942014 were also obtained and analyzed. At all the selected weather stations, wind speed and direction were measured using the anemometer and wind vane which were installed at the height of $10 \mathrm{~m}$. The instrument used for measuring the surface wind speed is rotating cup type anemometer where the cups are mounted symmetrically at right angle to a vertical shaft. Installing the anemometer at $10 \mathrm{~m}$ height is in accordance to ref. [11], which is basically for climatological and practical reason. It has been agreed that this elevation should be the standard meteorological reference level. The data on wind speed and direction were taken at 1 hour interval and stored in a data logger. The hourly wind speed and direction data for three years were analyzed in order to investigate the wind characteristics. The hottest ambient temperatures were analyzed and calculated to get UTCI values. In this study, UTCI was calculated by a program based on regression equation which is devised by International Society of Biometeorology Commission 6 by COST (European Cooperation in Science and Technology) Action 730 under the umbrella of the WMO Commission on Climatology [12]. The weather parameters, which include value of ambient temperature $\left({ }^{\circ} \mathrm{C}\right)$, solar radiation $\left(\mathrm{W} / \mathrm{m}^{2}\right)$, relative humidity $(\%)$, and wind speed $(\mathrm{m} / \mathrm{s})$ are required for the calculation of UTCI $\left({ }^{\circ} \mathrm{C}\right)[13]$.

\section{Universal Thermal Climate Index (UTCl)}

The UTCI is divided into 10 different stress levels which comprise no thermal stress, 4 heat stress levels, and 5 cold stress levels [14]. UTCI is stated as the equivalent ambient temperature of a reference environment that causes the same physiological response of a reference person as would the actual environment [15]. It is based on Fiala multi-node model [16] of human thermal regulation in combination with an adaptive clothing model. UTCI is appropriate for thermal assessments in all climates and seasons, and on any scale [12].

\section{Results and Discussion}

The determination of outdoor thermal comfort and wind characteristics were made by conducting detailed analysis on weather data such as ambient temperature, relative humidity, sun radiation, minmax wind speed, mean wind speed, wind direction and its frequency. Heat stress is one of the major concerns of this study. Figure 2 shows the monthly mean wind speed in three years. From the observation, the windiest months were in January and February which recorded approximately $1.84 \mathrm{~m} / \mathrm{s}$ and $1.87 \mathrm{~m} / \mathrm{s}$ respectively. The minimum mean wind speed indicated in the month of November was just below $1.40 \mathrm{~m} / \mathrm{s}$. On the following month, the mean wind speed tremendously increased up until the month of January before it gradually decreased until the month of April which might be due to northeast monsoon season. Between the months of April to November, the trend of mean wind speed showed gradual increase and reach a peak at about $1.73 \mathrm{~m} / \mathrm{s}$ before decreasing quite steeply due to southwest monsoon season.

Furthermore, the yearly mean wind speed for three years data analysis at Alor Setar, Kuantan, and Subang were at $1.70 \mathrm{~m} / \mathrm{s}, 1.69 \mathrm{~m} / \mathrm{s}$, and $1.6 \mathrm{~m} / \mathrm{s}$ respectively. The yearly mean wind speeds trend at all locations show only slight differences. The mode of wind speed at Kuantan expressed no wind 
movement at all (i.e. $0 \mathrm{~m} / \mathrm{s}$ ) as the dominant readings at $13.94 \%$ of frequency. Meanwhile, the remaining locations demonstrated calmness and no wind with the range of frequency from $10 \%$ to $13 \%$. On average, the maximum wind speed at all locations was about $10 \mathrm{~m} / \mathrm{s}$ except for Subang with the maximum wind speed of $11.6 \mathrm{~m} / \mathrm{s}$. The variations of yearly mean wind speed are also constant as the display values of standard deviation are in the range of 1.19 to 1.39 .

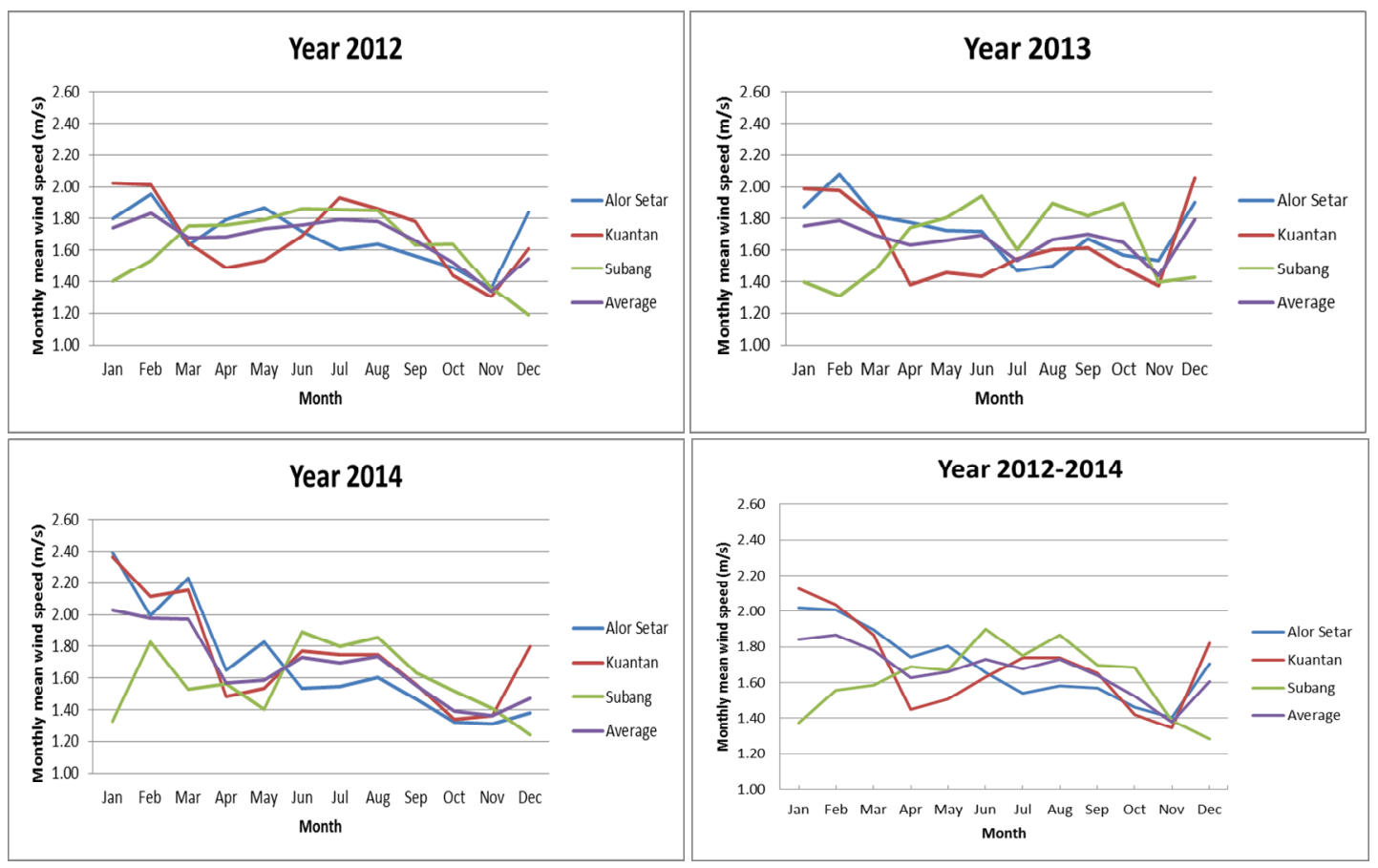

Figure 2. Monthly mean wind speeds at $10 \mathrm{~m}$ height for the selected sites.

Besides the value and trend of wind speed, the direction of the wind is the most significant in evaluating the possibilities of outdoor thermal comfort. The urban planner, architect and engineer can strategize the orientation of the building in order to increase building permeability and indirectly, will increase the induced wind as a matter of reducing urban heat island. In general, the annual trend of prevailing wind as shown in Table 2 in all locations sticks at the same North direction $\left(0^{\circ}\right)$ with average frequency of about $12.21 \%$. It indicates that Kuantan has the highest frequency which is at $13.94 \%$. In contrast, Alor Setar illustrates the less dominant wind direction with frequency at about $10.21 \%$.

Three years weather data were analyzed in order to obtain UTCI values at the worst heat stress cases. In general, it can be seen from Table 3 that during hottest temperatures, all the 3 locations experience extreme heat stress conditions, except for Kuantan which is slightly better with sometimes experiencing only very strong heat stress conditions. In the year 2012, Subang has the highest UTCI value of $47.6^{\circ} \mathrm{C}$. For the following year, the calculated UTCI value of $51.2^{\circ} \mathrm{C}$ for Alor Setar is the highest highlighting the most extreme heat stress condition as compared to the other locations. Meanwhile, in the next two years, Subang station once again experienced extreme heat stress condition with the highest calculated UTCI value of $49.7^{\circ} \mathrm{C}$. Based on Table 3 , the range of maximum heat stress in three years data are in between $42^{\circ} \mathrm{C}$ to $52^{\circ} \mathrm{C}$ at all locations which indicate occurrence of very strong heat stress and extreme heat stress conditions. Hence, it is worth to mention that heat stress would be a common problem in Peninsular Malaysia which would enhance people's level of discomfort especially to whom living in urban areas. The problem of urban heat island is crucial 


\section{IConCEES 2015}

nowadays which might be due to the variation of solar radiation and inadequate wind speed to wipe out the heat entrapped around the building.

Table 2. Annual wind rose distribution and frequency in the study.

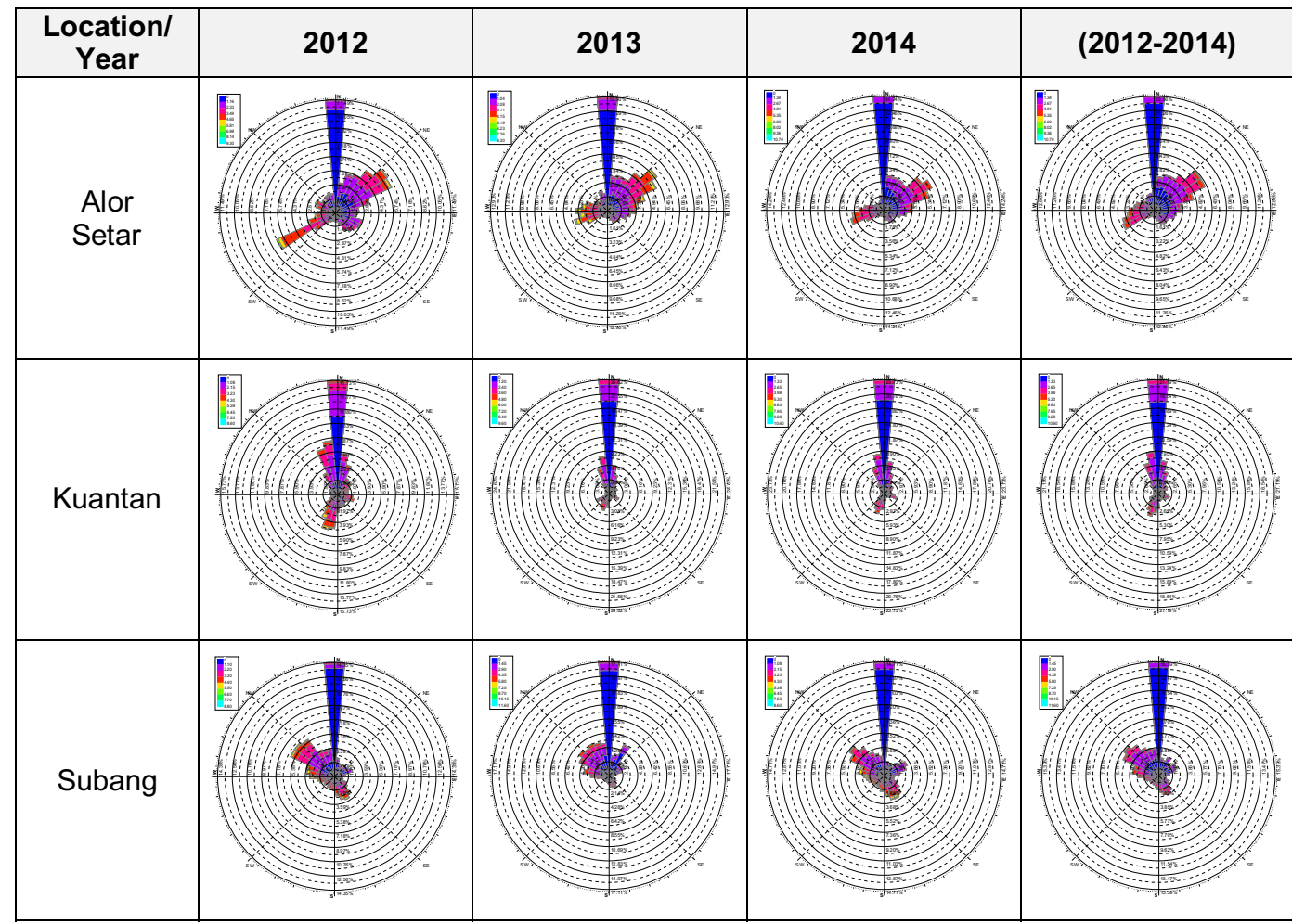

Table 3. Annual UTCI in the study at hottest temperature in 2012-2014 (3 years).

\begin{tabular}{|c|c|c|c|c|c|c|c|c|}
\hline Location & Date & Time & $\begin{array}{c}\text { Tem- } \\
\text { perature } \\
\left({ }^{\circ} \mathbf{C}\right)\end{array}$ & $\begin{array}{c}\text { Relative } \\
\text { Humidity } \\
\text { (\%) }\end{array}$ & $\begin{array}{l}\text { Wind } \\
\text { Speed } \\
(\mathrm{m} / \mathrm{s})\end{array}$ & $\begin{array}{c}\text { Solar } \\
\text { Radiation } \\
\left(\mathbf{W} / \mathbf{m}^{2}\right)\end{array}$ & $\begin{array}{c}\text { UT- } \\
\text { CI } \\
\left({ }^{\circ} \mathbf{C}\right)\end{array}$ & $\begin{array}{c}\text { Stress } \\
\text { Category }\end{array}$ \\
\hline \multirow{3}{*}{ Alor Setar } & 7.2.2012 & 1600 & 35.4 & 41 & 1.90 & 855.56 & 46.7 & $\begin{array}{c}\text { extreme } \\
\text { heat stress }\end{array}$ \\
\hline & 1.4 .2013 & 1500 & 37.2 & 42 & 1.70 & 1025.00 & 51.2 & $\begin{array}{c}\text { extreme } \\
\text { heat stress }\end{array}$ \\
\hline & 28.3.2014 & 1700 & 37.5 & 37 & 2.10 & 644.44 & 46.2 & $\begin{array}{c}\text { extreme } \\
\text { heat stress }\end{array}$ \\
\hline \multirow{3}{*}{ Kuantan } & 3.10 .2012 & 1600 & 34.5 & 52 & 4.00 & 702.78 & 43.2 & $\begin{array}{l}\text { very strong } \\
\text { heat stress }\end{array}$ \\
\hline & 19.6.2013 & 1600 & 36.0 & 48 & 4.80 & 758.33 & 45.1 & $\begin{array}{l}\text { very strong } \\
\text { heat stress }\end{array}$ \\
\hline & 24.4 .2014 & 1400 & 35.3 & 55 & 1.60 & 922.22 & 49.0 & $\begin{array}{c}\text { extreme } \\
\text { heat stress }\end{array}$ \\
\hline \multirow{3}{*}{ Subang } & 5.6 .2012 & 1500 & 36.4 & 49 & 6.7 & 938.89 & 47.6 & $\begin{array}{c}\text { extreme } \\
\text { heat stress }\end{array}$ \\
\hline & 18.6 .2013 & 1400 & 36.0 & 39 & 6.0 & 933.33 & 46.2 & $\begin{array}{c}\text { extreme } \\
\text { heat stress }\end{array}$ \\
\hline & 5.3 .2014 & 1500 & 37.8 & 17 & 3.4 & 1097.22 & 49.7 & $\begin{array}{c}\text { extreme } \\
\text { heat stress }\end{array}$ \\
\hline
\end{tabular}


By analyzing the 20 years weather data (1994-2014), the hottest days during that period for all the three locations were determined and together with other weather parameters their UTCI values were calculated as detailed in Table 4. Based on UTCI calculation, it was shown that the extreme heat stress conditions would occur at Alor Setar and Subang. Table 4 also shows that Subang has not only the highest UTCI value of $49.7^{\circ} \mathrm{C}$ but also the highest solar radiation intensity of $1097.22 \mathrm{~W} / \mathrm{m}^{2}$. Although Subang's solar radiation is $30 \%$ higher than that of Alor Setar, their UTCI values differ only slightly at $0.01{ }^{\circ} \mathrm{C}$. This might be due to the value of wind speed at Subang which is $47 \%$ higher at about $3.4 \mathrm{~m} / \mathrm{s}$ as compared to that of Alor Setar. Again, it is crucial to mention that wind speed variation plays an important factor affecting heat stress performance.

Table 4. UTCI index at the hottest temperature in 1994 to 2014 (20 years).

\begin{tabular}{|c|c|c|c|c|c|c|c|c|}
\hline Location & Date & Time & $\begin{array}{c}\text { Temp- } \\
\mathbf{e r a t u r e} \\
\left.\mathbf{(}{ }^{\circ} \mathbf{C}\right)\end{array}$ & $\begin{array}{c}\text { Relative } \\
\text { Humidity } \\
\mathbf{( \% )}\end{array}$ & $\begin{array}{c}\text { Wind } \\
\text { Speed } \\
\mathbf{( m / s )}\end{array}$ & $\begin{array}{c}\text { Solar } \\
\text { Radia- } \\
\text { tion } \\
\left(\mathbf{W} / \mathbf{m}^{\mathbf{2}} \mathbf{)}\right.\end{array}$ & $\begin{array}{c}\text { UT- } \\
\mathbf{C I} \\
\left({ }^{\circ} \mathbf{C}\right)\end{array}$ & $\begin{array}{c}\text { Stress } \\
\text { Category }\end{array}$ \\
\hline Alor setar & 27.3 .1998 & 1600 & 39.0 & 36 & 1.8 & 769.44 & 49.6 & $\begin{array}{c}\text { extreme heat } \\
\text { stress }\end{array}$ \\
\hline Kuantan & 26.5 .1998 & 1500 & 36.6 & 50 & 4.0 & 536.11 & 43.8 & $\begin{array}{c}\text { very strong } \\
\text { heat stress }\end{array}$ \\
\hline Subang & 5.3 .2014 & 1500 & 37.8 & 17 & 3.4 & 1097.22 & 49.7 & $\begin{array}{c}\text { extreme heat } \\
\text { stress }\end{array}$ \\
\hline
\end{tabular}

\section{Conclusion}

To recapitulate, there are several major findings from this study. The findings are the mean wind speed for three years data at Alor Setar, Kuantan, and Subang, were found to be $1.70 \mathrm{~m} / \mathrm{s}, 1.69 \mathrm{~m} / \mathrm{s}$, and $1.63 \mathrm{~m} / \mathrm{s}$ respectively. The highest hourly wind speed was observed to be $11.6 \mathrm{~m} / \mathrm{s}$ at Subang on $13^{\text {rd }}$ July 2013 at 4.00 p.m. It was also observed that no wind movement (i.e. $0 \mathrm{~m} / \mathrm{s}$ ) could be considered as the lowest hourly wind speed for all 3 locations, and Kuantan showed the highest frequency of calmness at $13.94 \%$. Alor Setar, Kuantan, and Subang demonstrated the prevailing wind from North direction $\left(0^{\circ}\right)$ with about $10 \%$ of frequencies. The extreme heat stress conditions were calculated to be at Alor Setar and Subang as the latest trend of UTCI in year 2012 to 2014. Meanwhile, Kuantan demonstrated very strong heat stress conditions. The 20 years weather data from 1994 to 2014 were analyzed where the values of UTCI at Alor Setar, Kuantan, and Subang were $49.6^{\circ} \mathrm{C}, 43.8^{\circ} \mathrm{C}$, and $49.7^{\circ} \mathrm{C}$ respectively. Here, it should be noted that the current work is just a preliminary study in estimating the prevailing wind and wind speed in order to have a comprehensive wind data base for obtaining a good prediction of outdoor thermal comfort. Apart from that, this study can also contribute towards the awareness on the current level of heat stress problem in Peninsular Malaysia. Ultimately, it is hope that the overall findings from this study can be beneficial to researchers, state's authorities and country's policy makers for achieving a sustainable environment.

\section{Acknowledgements}

The author would like to express gratitude to Ministry of Education Malaysia and Universiti Tun Hussein Onn Malaysia for funding this study, Malaysian Meteorological Department for providing weather data, and all individuals for their help throughout the course of this research study. 


\section{References}

[1] A. Mochida and I.Y.F. Lun, Prediction of wind environment and thermal comfort at pedestrian level in urban area, J. Wind Eng. Ind. Aerodyn., 96(10-11), 1498-1527, (2008).

[2] A. Abd Razak, A. Hagishima, N. Ikegaya and J. Tanimoto, Analysis of airflow over building arrays for assessment of urban wind environment, Build Environ., 59, 56-65, (2013).

[3] T, Asawa, A. Hoyano, and K. Nakaohkubo, Thermal design tool for outdoor spaces based on heat balance simulation using a 3D-CAD system, Build Environ., 43(12), 2112-2123, (2008).

[4] A.H. Abdullah and F. Wang, Design and low energy ventilation solutions for atria in the tropics, Sustain Cities Soc., 2(1), 8-28, (2012).

[5] F. Wang and A.H. Abdullah, Investigating thermal conditions in a tropic atrium employing CFD and DTM techniques, Int. J. Low-Carbon Technol., 6, 171-186, (2011).

[6] N. Makaremi, E. Salleh, M.Z. Jaafar and A. Ghaffarian Hoseini, Thermal comfort conditions of shaded outdoor spaces in hot and humid climate of Malaysia, Build Environ., 48, 7-14, (2012).

[7] Malaysian Meteorological Department, Malaysia Weatherwise Malaysia. <available at: http://www.met.gov.my>

[8] J. Hang, Y. Li, M. Sandberg, R. Buccolieri and S. Di Sabatino, The influence of building height variability on pollutant dispersion and pedestrian ventilation in idealized high-rise urban areas, Build Environ., 56, 346-360, (2012).

[9] J. Hang, Y. Li and M. Sandberg, Experimental and numerical studies of flows through and within high-rise building arrays and their link to ventilation strategy, J. Wind Eng. Ind. Aerodyn., 99(10), 1036-1055, (2011).

[10]T. Kubota, M. Miura, Y. Tominaga and A. Mochida, Wind tunnel tests on the relationship between building density and pedestrian-level wind velocity: Development of guidelines for realizing acceptable wind environment in residential neighbourhoods, Build Environ., 243(10), 1699-1708, (2008).

[11]B.D. Katsoulis, Theoretical and Applied Climatology, (1993).

[12]G. Jendritzky, R. de Dear and G. Havenith, UTCI-Why another thermal index?, Int. J. Biometeorol., 56, 421-428, (2012).

[13]Climate Chip, Climate change health impact and prevention. <available at: www.climatechip.org>

[14] Glossary of Terms for Thermal Physiology, Journal of Thermal Biology, 28, 75-106, (2003).

[15]K. Blazejczyk, Y. Epstein, G. Jendritzky, H. Staiger and B. Tinz, Comparison of UTCI to selected thermal indices, Int. J. Biometeorol., 56, 515-535, (2012).

[16]D. Fiala, K.J. Lomas and M. Stohrer, A computer model of human thermoregulation for a wide range of environmental conditions: The passive system, J. Appl. Physiol., 87, (1999). 